\title{
Pigment Production under Cold Stress in the Green Microalga Chlamydomonas reinhardtii
}

\author{
Supakorn Potijun ${ }^{1,2}\left(\mathbb{D}\right.$, Chonlada Yaisamlee ${ }^{1,2}$ and Anchalee Sirikhachornkit ${ }^{1,2, *}$ \\ 1 Department of Genetics, Faculty of Science, Kasetsart University, Bangkok 10900, Thailand; \\ supakorn.pot@ku.th (S.P.); cholsummerstop@gmail.com (C.Y.) \\ 2 Center for Advanced Studies in Tropical Natural Resources, National Research University-Kasetsart \\ University (CASTNAR, NRU-KU), Kasetsart University, Bangkok 10900, Thailand \\ * Correspondence: anchalee.si@ku.th; Tel.: +66-2562-5444; Fax: +66-2579-5528
}

Citation: Potijun, S.; Yaisamlee, C.; Sirikhachornkit, A. Pigment

Production under Cold Stress in the Green Microalga Chlamydomonas reinhardtii. Agriculture 2021, 11, 564. https://doi.org/10.3390/ agriculture11060564

Academic Editors: Maria Giordano and Christophe El-Nakhel

Received: 31 May 2021

Accepted: 19 June 2021

Published: 20 June 2021

Publisher's Note: MDPI stays neutral with regard to jurisdictional claims in published maps and institutional affiliations.

Copyright: (c) 2021 by the authors. Licensee MDPI, Basel, Switzerland. This article is an open access article distributed under the terms and conditions of the Creative Commons Attribution (CC BY) license (https:/ / creativecommons.org/licenses/by/ $4.0 /)$.

\begin{abstract}
Microalgae have long been used for the commercial production of natural colorants such as carotenoids and chlorophyll. Due to the rising demand for carotenoids and other natural products from microalgae, strategies to increase production efficiency are urgently needed. The production of microalgal biorefineries has been limited to countries with moderate climates. For countries with cooler climates and less daylight, methodologies for the efficient production of microalgal biorefineries need to be investigated. Algal strains that can be safely consumed as whole cells are also attractive alternatives for developing as carotenoid supplements, which can also contain other compounds with health benefits. Using such strains helps to eliminate the need for hazardous solvents for extraction and several other complicated steps. In this study, the mesophilic green alga Chlamydomonas reinhardtii was employed to study the effects of cold stress on cell physiology and the production of pigments and storage compounds. The results showed that temperatures between 10 and $20^{\circ} \mathrm{C}$ induced carotenoid and chlorophyll accumulation in the wild-type strain of $C$. reinhardtii. Interestingly, the increased level of carotenoids suggested that they might play a crucial role in cold stress acclimation. A temperature of $15^{\circ} \mathrm{C}$ resulted in the highest carotenoid and chlorophyll productivity. At this temperature, carotenoid and chlorophyll productivity was 2 times and 1.3 times higher than at $25^{\circ} \mathrm{C}$, respectively. Subjecting a mutant defective in lutein and zeaxanthin accumulation to cold stress revealed that these two carotenoids are not essential for cold stress survival. Therefore, cold temperature could be used as a strategy to induce and increase the productivity of pigments in C. reinhardtii.
\end{abstract}

Keywords: cold acclimation; carotenoid; chlorophyll; Chlamydomonas; functional foods

\section{Introduction}

Cold stress is one of the major environmental stresses that limit the growth and development of plants and algae [1-3]. To maintain cellular activities under cold stress, cells require several protective physiological and morphological mechanisms, including the synthesis of pigments. Carotenoids are 40-carbon tetraterpene pigments synthesized in plants, algae, and some fungi. In photosynthetic organisms, they function as accessory pigments and as a crucial antioxidant for neutralizing free radicals. In humans, carotenoids act as a precursor for vitamin A synthesis. They are effective antioxidants and possess cancer-preventive activity [4]. In the industrial sector, carotenoids are used as colorants in food and beverages [5]. Humans cannot synthesize carotenoids but must obtain them from food sources. As synthetic carotenoids are less effective in terms of their health-promoting properties, there is a steeply rising demand for natural carotenoids [6]. Strategies for improving the production of natural carotenoids are therefore necessary.

One of the most widely known carotenoid supplements is $\beta$-carotene. Currently, $97-98 \%$ of $\beta$-carotene in the market is in synthetic form [7]. However, a natural form of $\beta$ carotene, which is composed of both all-trans and 9-cis isomers as opposed to the all-trans 
isomer in synthetic form, possesses more beneficial properties [6]. A major source of natural $\beta$-carotene extract is Dunaliella salina, a microalga that is highly salt tolerant. Production of this carotenoid involves growing cells in a nutrient-rich medium to obtain a large amount of biomass, then introducing nutrient stress to induce $\beta$-carotene accumulation, followed by extraction and purification $[8,9]$.

Chlorophyll is the major photosynthetic pigment that harvests light energy. In green algae, two main types of chlorophyll exist, which are chlorophyll $a$ and chlorophyll $b$. Other than its main function in the photosystems, chlorophyll is one of the high value bioactive compounds that can be extracted for use as a health supplement [10]. Chlorophyllin, a chlorophyll derivative, is also used as a food colorant and a supplement [11]. The potential health benefits of a diet rich in chlorophylls were indicated in a recent study and include ulcer healing, antioxidant activity, and antiviral activity [12].

Chlamydomonas reinhardtii is a mesophilic green alga that has long been used as a model organism for studying various biological processes [9]. Its ease of cultivation, rapid doubling time, the ability to grow heterotrophically, and the availability of genome sequencing and molecular tools have popularized this alga in recent years. It has been suggested as an excellent system for the production of carotenoids and chlorophyll [13,14]. Interestingly, Chlamydomonas was recently categorized under Generally Regarded as Safe (GRAS) status for human consumption [8]. Reports from studies in mice and humans have shown that regular consumption of this alga improves the digestive and excretory system, while no genotoxicity or any side effects were found $[15,16]$. The idea of developing this alga as a food supplement in whole cell form has been suggested. In fact, it was recently reported that Chlamydomonas possesses a higher potential as a food supplement than the well-known Chlorella and Spirulina [17].

Carotenoid accumulation has been reported to be induced by cold temperature in plants and Streptophycean green algae $[18,19]$. With some parts of the world experiencing a cooler climate either in the winter season or all year long, finding conditions that allow carotenoid production in such suboptimal conditions is beneficial for better use of the land area. More importantly, using algal strains that are safe to consume as whole cells is an attractive alternative approach for producing high-value products. Complicated steps for extraction can be eliminated and packaging can be simplified, thus reducing production costs. In addition, eliminating the use of hazardous solvents for extraction is more attractive for the environment and is safer for consumption in the eye of the consumer.

Certain types of carotenoids might be required for survival of microalgae under a specific stress. For example, lutein and zeaxanthin together were shown to be required for the survival of C. reinhardtii under high light stress [20]. Under this condition, the $n p q 1$ lor1 mutant $C$. reinhardtii lacking these two carotenoids bleached and died [20]. Moreover, the lack of lutein in this mutant was compensated by overaccumulation of $\beta$-carotene [21]. There is very little information regarding the response of mesophilic green algae to cold treatment in the literature, and whether or not lutein and zeaxanthin are also required for cold stress survival is not known. In this work, the physiological responses of the mesophilic green alga C. reinhardtii to cold temperature, ranging from $5^{\circ} \mathrm{C}$ to $25^{\circ} \mathrm{C}$, were explored. Our results suggest that cultivation of $C$. reinhardtii under cold temperature can be used to increase the productivity of biomass and pigments.

\section{Materials and Methods}

\subsection{Algal Strains and Culture Conditions}

C. reinhardtii wild-type $4 \mathrm{~A}+$ and the npq1lor 1 mutant strains were provided by Prof. Krishna Niyogi (University of California, Berkeley). Cultures were grown in Tris-acetatephosphate (TAP) medium under constant illumination at $50 \mu \mathrm{mol}$ photons $\mathrm{m}^{-2} \mathrm{~s}^{-1}$ at $25^{\circ} \mathrm{C}$. Log phase cultures were diluted to a density of $2 \times 10^{6}$ cells $\mathrm{mL}^{-1}$. To investigate the effect of cold stress on the growth of Chlamydomonas, cells were incubated under $5^{\circ} \mathrm{C}$, $10^{\circ} \mathrm{C}, 15^{\circ} \mathrm{C}, 20^{\circ} \mathrm{C}$, and $25^{\circ} \mathrm{C}$ and growth was monitored over the course of $72 \mathrm{~h}$. Cultures were placed in the dark under the indicated temperature by wrapping the flasks with 
aluminium foil. Cells were collected at the indicated time points and stored at $-80{ }^{\circ} \mathrm{C}$ until used.

\subsection{Growth and Biomass Measurement}

Log phase cultures were diluted to a density of $0.5 \times 10^{6}$ cells $\mathrm{mL}^{-1}$. These cultures were incubated under $5{ }^{\circ} \mathrm{C}, 10^{\circ} \mathrm{C}, 15^{\circ} \mathrm{C}, 20^{\circ} \mathrm{C}$, and $25^{\circ} \mathrm{C}$ in the dark. Sampling was performed at $0,24,48$, and $72 \mathrm{~h}$ by taking $1 \mathrm{~mL}$ of each culture and measuring the optical density at $750 \mathrm{~nm}$.

To determine the biomass dry weight, $100 \mathrm{~mL}$ of culture was harvested and centrifuged at $7500 \mathrm{rpm}$ for $5 \mathrm{~min}$. The supernatant was discarded, and the pellet was dried at $105^{\circ} \mathrm{C}$ for $24 \mathrm{~h}$, cooled to room temperature, and weighed.

\subsection{Photosynthetic Pigment Content}

The photosynthetic pigments were extracted from $1 \mathrm{~mL}$ of culture using $1 \mathrm{~mL}$ of $80 \%$ acetone. The mixture was extracted by vortexing the cells until the pellets were white. The supernatant was assayed spectrophotometrically, and the quantity of the pigment was calculated based on a previously reported formula [22].

\subsection{Starch and Lipid Production}

Cells were harvested and lyophilized at $-50{ }^{\circ} \mathrm{C}$. Twenty to thirty milligrams of each sample were sonicated for $15 \mathrm{~min}$. Starch was measured using the Total Starch (AA/AMG) assay kit from Megazyme (Ireland), according to the manufacturer's protocols for starch samples that also contain D-glucose [23]. The total lipid was quantified using Vanillin assay [24].

\subsection{Calculation of Productivities}

Volumetric biomass productivity $P_{\text {Biomass }}\left(\mathrm{g} \mathrm{L}^{-1}\right.$ day $\left.^{-1}\right)$ was calculated based on a previously reported formula (equation 1) [25]. The productivity of starch, lipid, and pigments were calculated by

$$
P_{\text {starch,lipid,chlorophylll,carotenoid }}=P_{\text {Biomass }} \times \mathrm{C}_{\mathrm{f}}
$$

where $P_{\text {Biomass }}$ is productivity of biomass; and $C_{\mathrm{f}}$ is the final content of starch, lipid, chlorophyll, or carotenoids, and was given as percent dry weight.

\subsection{Statistical Analysis}

For comparison of cell density, total lipid, starch, and pigment content of the wild-type cells cultivated at various temperature, the temperature of $25{ }^{\circ} \mathrm{C}$ was used as a control. Statistical analyses were conducted using the SPSS version 22.0. Analysis of variance (ANOVA) was calculated to determine statistical significance $(p<0.05)$. For comparison of the wild-type stain and the npq1 lor 1 mutant strain, the Student's $t$-test was used to calculate significant difference $(p<0.05)$. All experiments were performed with three biological replicates and the results are expressed as mean values \pm standard deviation (SD).

\section{Results and Discussion}

\subsection{Effect of Hypothermal Stress on Growth of WT}

Low temperature can have negative impacts on the growth and productivity of plants and algae [1-3]. Compared to plants, little information is known about the physiological responses of microalgae under cold stress. Under $5{ }^{\circ} \mathrm{C}$, no growth was observed as indicated by a flat line (Figure 1). A previous study also found that under this temperature, Chlamydomonas cells did not show a significant increase in cell density but an increase in cell volume was observed [26]. At $10^{\circ} \mathrm{C}$, cells densities were similar to those at $5{ }^{\circ} \mathrm{C}$ with slightly higher values at 48 and $72 \mathrm{~h}$. Cells cultivated under $15^{\circ} \mathrm{C}$ grew at the same rate as the $25^{\circ} \mathrm{C}$ control in the first $48 \mathrm{~h}$. At $72 \mathrm{~h}$, cells under this condition grew slightly but significantly better than the control. Interestingly, the best temperature for growth was 
at $20^{\circ} \mathrm{C}$ where the density was significantly higher than at the $25^{\circ} \mathrm{C}$ control at all time points. In terms of biomass productivity, the temperature of $20^{\circ} \mathrm{C}$ was best and slightly better than the $25^{\circ} \mathrm{C}$ control (Table 1). The temperatures of $10^{\circ} \mathrm{C}$ and $15^{\circ} \mathrm{C}$ gave similar productivity, which was slightly lower than that of the control. The results are in line with several previous studies in microalgae that have reported optimal growth temperatures in the range of $15{ }^{\circ} \mathrm{C}-25^{\circ} \mathrm{C}$, while there is a sharp decrease in growth below $10{ }^{\circ} \mathrm{C}$ [27-29].

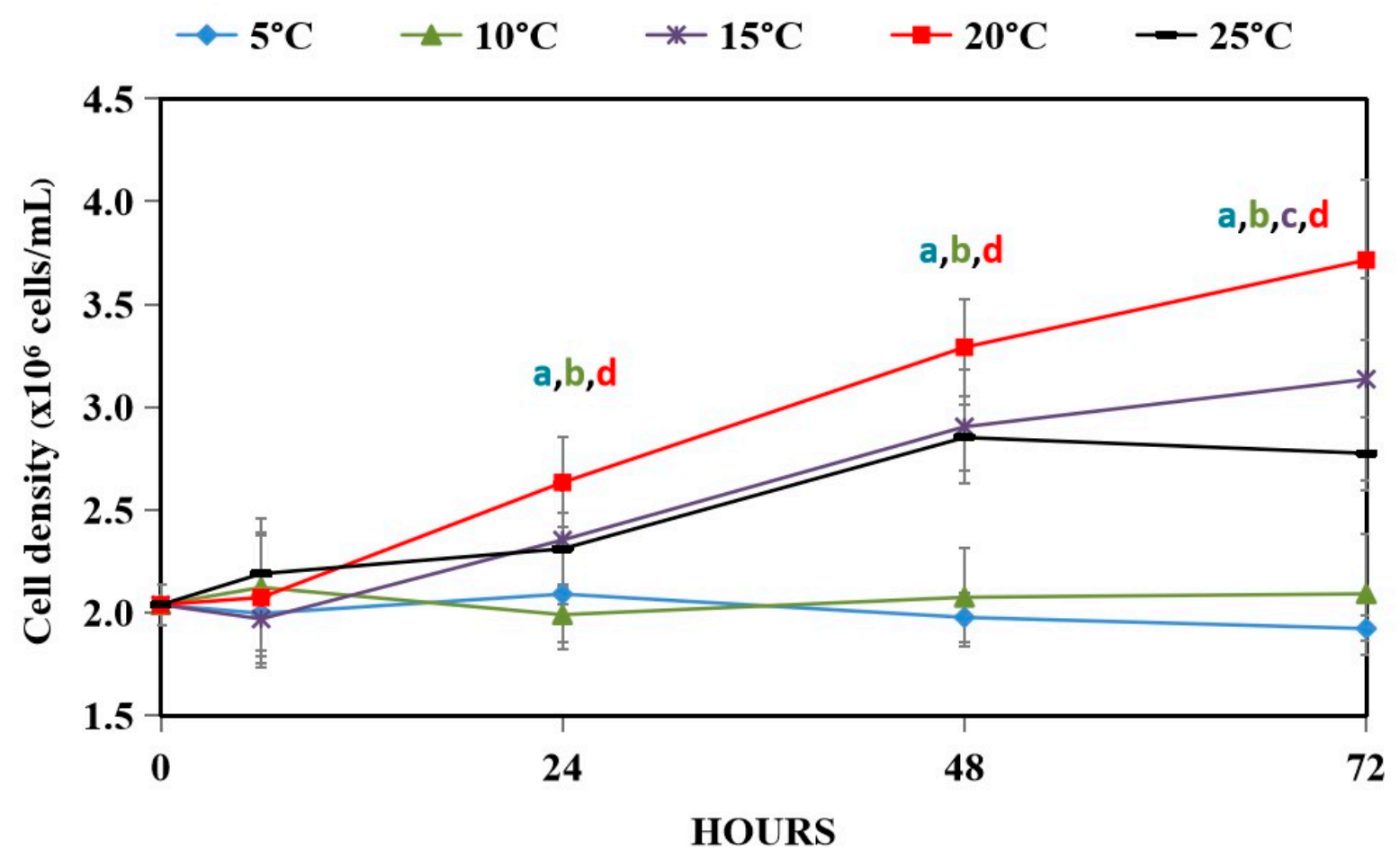

Figure 1. Growth of $C$. reinhardtii under different temperatures. All data are means \pm SD of three biological replicates. Different lowercase letters indicate significant differences between $25^{\circ} \mathrm{C}$ and each temperature $(p<0.05)$.

Table 1. The productivity of biomass, starch, lipid, chlorophyll, and carotenoids. All data are means \pm SD of three biological replicates. Significant differences between $25^{\circ} \mathrm{C}$ and each temperature are indicated by asterisks $\left(^{*}\right)(p<0.05)$.

\begin{tabular}{|c|c|c|c|c|c|}
\hline & \multicolumn{5}{|c|}{ Productivity } \\
\hline & $5^{\circ} \mathrm{C}$ & $10^{\circ} \mathrm{C}$ & $15^{\circ} \mathrm{C}$ & $20^{\circ} \mathrm{C}$ & $25^{\circ} \mathrm{C}$ \\
\hline $\begin{array}{c}\text { Biomass } \\
\left(\mathrm{g} \mathrm{L}^{-1} \text { day }^{-1}\right)\end{array}$ & $1.23 \pm 0.08^{*}$ & $1.75 \pm 0.11^{*}$ & $1.76 \pm 0.14$ * & $2.01 \pm 0.09 *$ & $1.95 \pm 0.06$ \\
\hline $\begin{array}{c}\text { Starch } \\
\left(\mathrm{mg} \mathrm{L}^{-1} \mathrm{day}^{-1}\right)\end{array}$ & $54.97 \pm 2.15$ * & $94.59 \pm 3.27$ & $124.24 \pm 4.21 *$ & $135.00 \pm 5.62 *$ & $100.00 \pm 4.43$ \\
\hline $\begin{array}{c}\text { Lipid } \\
\left(\mathrm{mg} \mathrm{L}^{-1} \mathrm{day}^{-1}\right)\end{array}$ & $163.73 \pm 4.28 *$ & $499.98 \pm 3.76$ * & $256.38 \pm 2.54$ * & $871.58 \pm 5.94$ * & $1016.99 \pm 4.11$ \\
\hline $\begin{array}{c}\text { Chlorophyll } \\
\left(\mathrm{mg} \mathrm{L}^{-1} \text { day }^{-1}\right)\end{array}$ & $31.79 \pm 1.15^{*}$ & $43.39 \pm 0.97$ & $55.18 \pm 2.01 *$ & $48.83 \pm 1.96^{*}$ & $40.37 \pm 1.41$ \\
\hline $\begin{array}{l}\text { Carotenoids } \\
\left(\mathrm{mg} \mathrm{L}^{-1} \text { day }^{-1}\right)\end{array}$ & $7.09 \pm 0.19$ & $9.80 \pm 0.51 *$ & $13.48 \pm 0.32 *$ & $10.55 \pm 0.08^{*}$ & $6.69 \pm 0.41$ \\
\hline
\end{tabular}

In the past decade, the utilization of microalgae for biomass, biofuels, and bioproducts has grown tremendously. Nevertheless, many microalgal products, especially oil for biofuels, are still far from commercial realization due to the cost of production. Moreover, for countries situated in the Northern Hemisphere, a major factor that hinders algal growth in open raceway ponds is a seasonal limitation for optimal growth [30-32]. If cultivation 
can be performed under sub-optimal temperatures by shifting to a different product that accumulates better under this condition, there will be a better use of facilities and land area. Approaches to improve growth under cold temperatures have also been reported. For example, a study of $C$. zofingiensis was performed by regulating $\mathrm{pH}$ with acetic acid to improve growth efficiency in winter in artificial wastewater [33].

\subsection{Energy Storage Compounds of WT under Hypothermal Stress}

Under abiotic stresses, microalgae accumulate lipids and starch for a storage compound as a crucial part of their survival mechanism [34]. Starch is known as a primary carbon and energy storage [33,35]. It is known to be essential for cell division even in the dark [36]. In this study, both lipids and starch levels were measured over the course of $72 \mathrm{~h}$ under hypothermal stress. In the range of $5-15{ }^{\circ} \mathrm{C}$, the lower the temperature, the lower the levels of both compounds observed (Figure 2A,B). At $20^{\circ} \mathrm{C}$, the level of lipids was lower than at $25{ }^{\circ} \mathrm{C}$ except at $48 \mathrm{~h}$ where the level at $20^{\circ} \mathrm{C}$ was significantly higher (Figure 2A). For starch, the level at $20^{\circ} \mathrm{C}$ was generally higher than that of the control at $25^{\circ} \mathrm{C}$ (Figure 2B). By comparing both lipids and starch, it was clear that starch level showed a greater increase over the course of $72 \mathrm{~h}$. When calculated in terms of productivity over the entire three days, lipid productivity peaked at $25^{\circ} \mathrm{C}$ and low temperature decreased its productivity (Table 1). In contrast, the productivity of starch was highest at $20^{\circ} \mathrm{C}$ followed by $15^{\circ} \mathrm{C}$. Therefore, cold temperatures increased the accumulation of starch but decreased total lipid accumulation.

$\mathbf{A}$

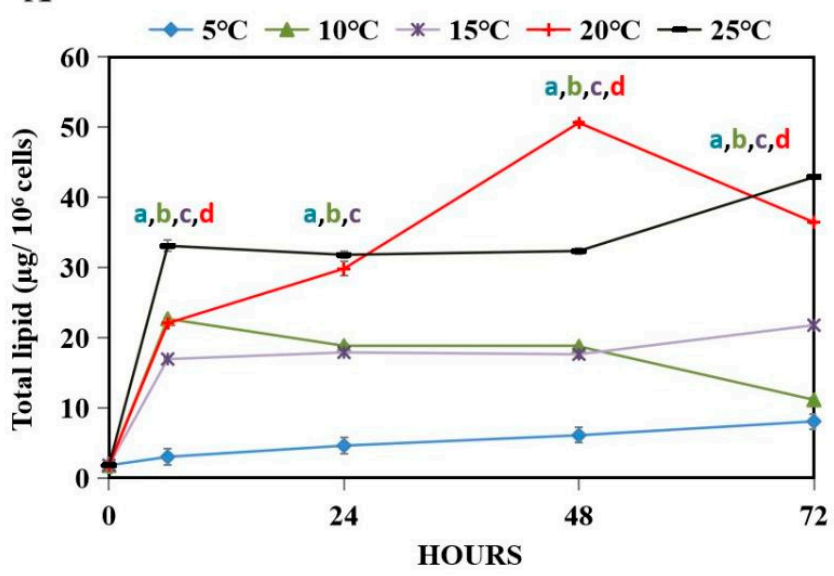

B

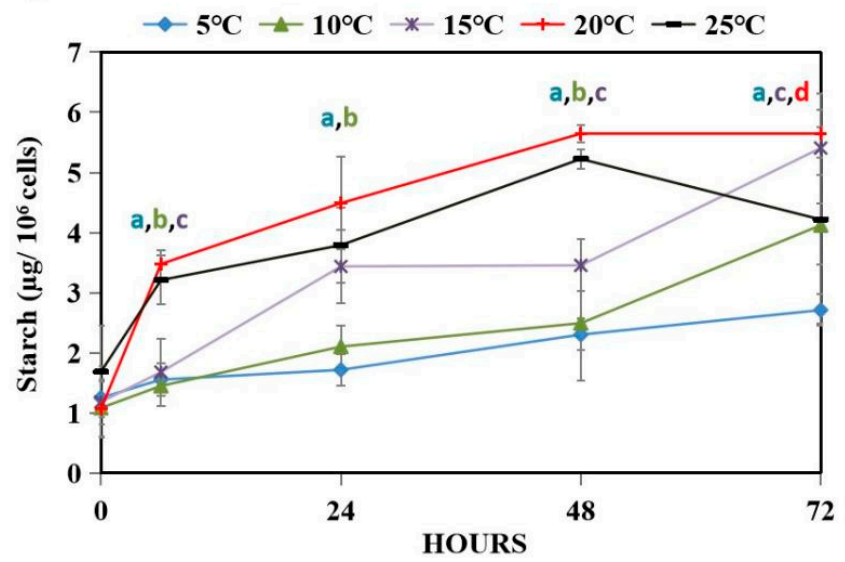

Figure 2. Lipid (A) and starch (B) content of C. reinhardtii cultivated under different temperatures. All data are means \pm SD of three biological replicates. Different lowercase letters indicate significant differences between $25{ }^{\circ} \mathrm{C}$ and each temperature $(p<0.05)$.

Metabolomic and proteomic data of Chlamydomonas treated with cold stress at $5{ }^{\circ} \mathrm{C}$ revealed that gluconeogenesis and starch synthesis were activated, leading to starch accumulation [26]. In our study, cold temperatures at $15{ }^{\circ} \mathrm{C}$ and $20^{\circ} \mathrm{C}$ resulted in higher starch productivity compared to at $25^{\circ} \mathrm{C}$ (Table 1). In the case of lipids, treating Chlamydomonas with cold stress at $5^{\circ} \mathrm{C}$ resulted in a decrease in lipid fraction [26]. Our results also showed that the production of lipid decreased with low temperature (Table 1).

\subsection{Photosynthetic Pigment Accumulation of WT under Hypothermal Stress}

Even though algal responses to many abiotic stresses have been reported, cold stress has not been extensively explored in terms of pigment production. From the culture subjected to different cold temperatures, the levels of the main pigments, chlorophyll and carotenoids, were monitored. A sharp decrease in the levels of both pigments was observed in cells grown under $5{ }^{\circ} \mathrm{C}$ in the first $48 \mathrm{~h}$, with a slight recovery at $72 \mathrm{~h}$ (Figure $3 \mathrm{~A}, \mathrm{~B}$ ). At $25^{\circ} \mathrm{C}$, the levels of both pigments were stabilized. Interestingly, the level of chlorophyll 
slightly increased at $10{ }^{\circ} \mathrm{C}$ and $20^{\circ} \mathrm{C}$ but exhibited a steep increase starting at the first $6 \mathrm{~h}$ when cells were subjected to $15^{\circ} \mathrm{C}$ treatment (Figure 3A). In the case of carotenoids, a chilling temperature between 10 and $20^{\circ} \mathrm{C}$ led to a significant increase in this pigment compared to the control. The productivity of both chlorophyll and carotenoid were best at $15{ }^{\circ} \mathrm{C}$ followed by $20^{\circ} \mathrm{C}$ (Table 1$)$.

A

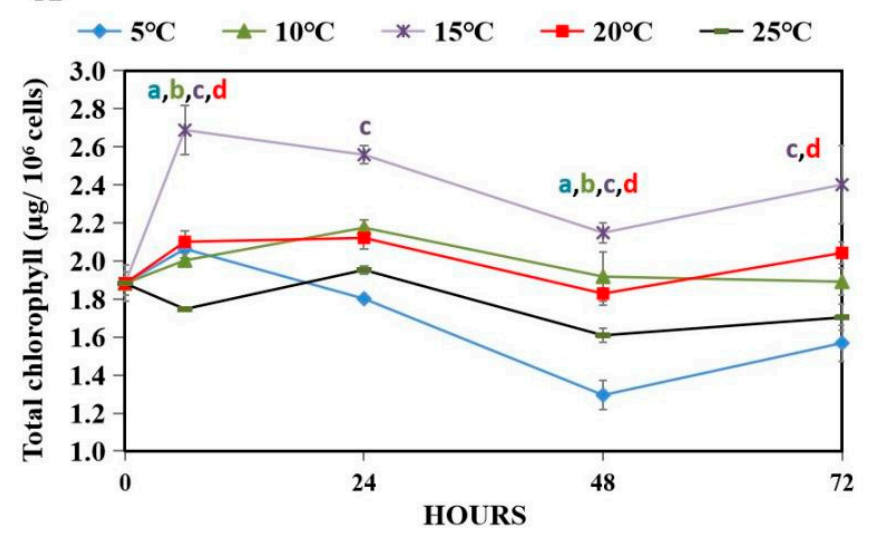

B

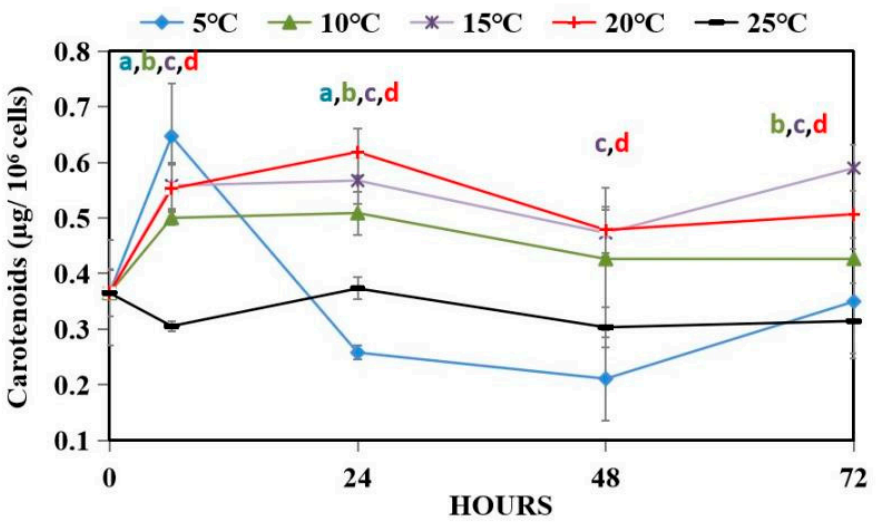

Figure 3. Chlorophyll (A) and carotenoid (B) content of $C$. reinhardtii cultivated under different temperatures. All data are means \pm SD of three biological replicates. Different lowercase letters indicate significant differences between $25^{\circ} \mathrm{C}$ and each temperature $(p<0.05)$.

Previous studies have shown that cold-exposed green algae significantly increased the content of photoprotective pigments such as antheraxanthin, zeaxanthin, and total carotenoids [18,37]. In the diatom Skeletonema costatum, the chlorophyll content also increased with a lower growth temperature [38]. Under cold stress in the presence of light, several factors such as higher oxygen solubility, overreduction of the electron transport chain in the chloroplasts, and mitochondria contribute to increased levels of reactive oxygen species (ROS) [39,40]. In fact, cold stress led to ROS accumulation in plants and Chlamydomonas [41-44]. Furthermore, ROS have been reported to induce carotenoid biosynthesis gene expressions, leading to carotenoid accumulation in Chlamydomonas, Dunaliella, and Haematococcus [26,45]. Even though a major site of ROS production in green algae is the chloroplast, there will still be ROS generated in the dark, mainly through the mitochondria. Because carotenoids are non-enzymatic antioxidants that can effectively sequester ROS [46], carotenoid accumulation is crucial for ROS elimination under cold stress. In fact, a study has reported that cold and dark treatments increased carotenoid content in Nannochloropsis oceanica [47]. Moreover, C. zofingiensis cultivated in the dark was able to produce high level of astaxanthin [48]. Other than photosynthetic organisms, a recent report into the bacterium Staphylococcus xylosus also showed that carotenoids play an important role in cold adaptation through the regulation of membrane fluidity [49]. Taken together, these studies suggest that carotenoids are crucial in the cold adaptation mechanism.

\subsection{Responses of the npq1lor1 Mutant to Cold Stress}

In Chlamydomonas, the two major carotenoids are lutein and $\beta$-carotene, which are on the $\alpha$-branch and the $\beta$-branch, respectively $[14,21]$. $\beta$-carotene is a precursor of zeaxanthin, which, together with lutein, has been shown to be essential for high light stress survival [20]. A previously characterized mutant npq1 lor1, which is defective in both lutein and zeaxanthin synthesis (Figure 4) [21], was then employed to investigate the importance of these carotenoids on cold acclimation. Additionally, this mutant accumulated a double level of $\beta$-carotene to compensate for the loss of lutein on the $\alpha$-branch [20,21]. Similar compensation was also shown in the cyanobacterium Synechocystis sp. PCC6803. Deficient in xanthophylls, it increased the content of $\beta$-carotene as compensation (Figure 4) [50]. 
In Arabidopsis lut 2 mutants deficient in lutein, a higher accumulation of $\beta$-carotene was observed [51]. Therefore, this characteristic makes it an attractive strain for improved $\beta$-carotene production.

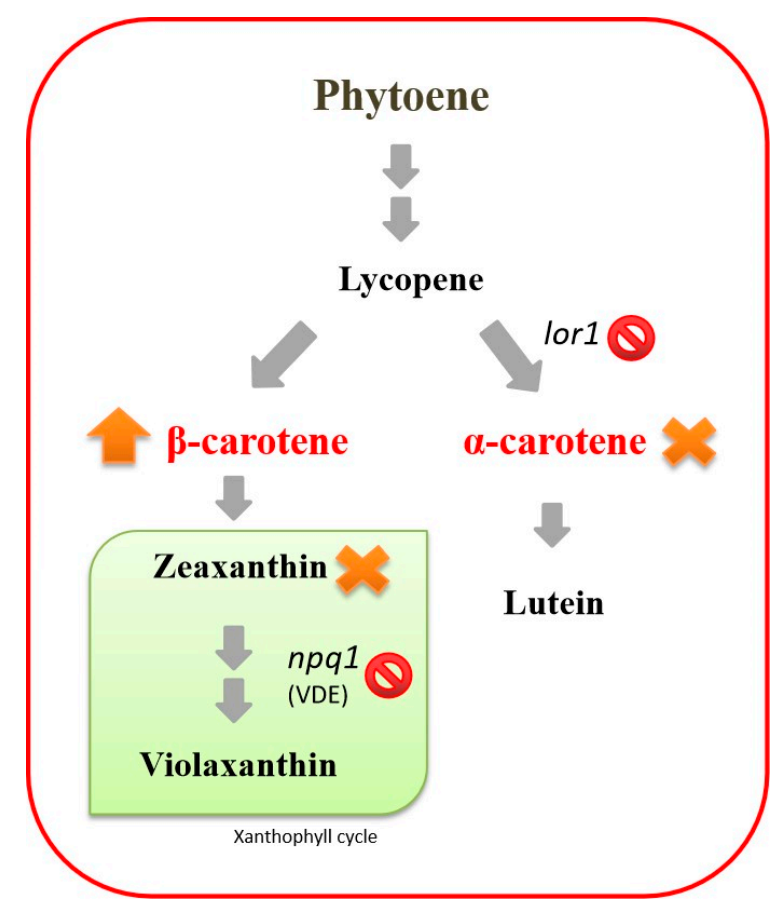

Figure 4. Simplified pathways for carotenoid synthesis and xanthophyll cycle in npq1 lor1 mutant (VDE; violaxanthin de-epoxidase).

Growth and pigment accumulation were monitored in $n p q 1$ lor 1 and compared to the WT over the course of $72 \mathrm{~h}$ under different temperatures. There was essentially no difference in cell density between the two strains under all temperatures (Figure 5A). In contrast, WT seemed to exhibit higher chlorophyll content under all temperatures, especially at $25^{\circ} \mathrm{C}$ where the differences between the two strains were significant at all time points (Figure 5B). Similarly, the carotenoid content of the WT was higher than that of the mutant at $20{ }^{\circ} \mathrm{C}$ and at $25^{\circ} \mathrm{C}$, except at $72 \mathrm{~h}$ at $20^{\circ} \mathrm{C}$ where the content of the two strains were similar (Figure 5C). Interestingly, at lower temperatures of $5{ }^{\circ} \mathrm{C}, 10^{\circ} \mathrm{C}$, and $15^{\circ} \mathrm{C}$, the carotenoid content of the two strains were similar except at the end of experiment at $10^{\circ} \mathrm{C}$, and at $15{ }^{\circ} \mathrm{C}$ where the carotenoid level of the WT was higher than that of the mutant (Figure 5C).

These results suggest that the lack of lutein and zeaxanthin did not have a significant effect on survival and growth under hypothermal stress of Chlamydomonas. Lutein and zeaxanthin function in the chloroplasts and have been shown to be crucial for photoprotection mechanisms in Chlamydomonas [20]. Because our studies were performed in the dark, the ROS generated from the chloroplasts can be neglected. Interestingly, a similar mutant in Arabidopsis, npq1lut2, lacking zeaxanthin and lutein was able to survive high light treatment even in the presence of cold temperature [52,53]. Therefore, the requirement of certain carotenoids for different stresses could be different between algae and higher plants. 
A

$5^{\circ} \mathrm{C}$

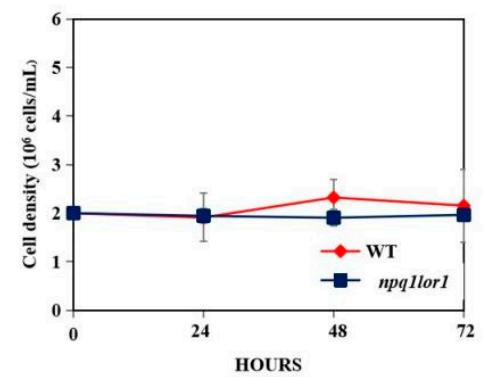

B
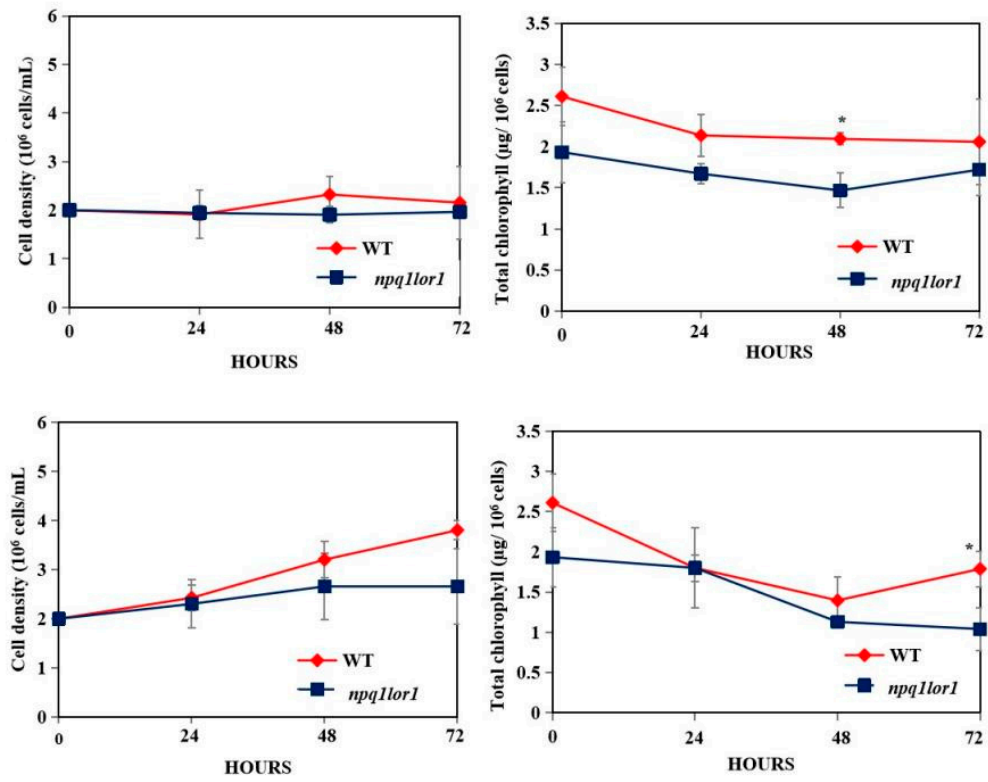

$10^{\circ} \mathrm{C}$
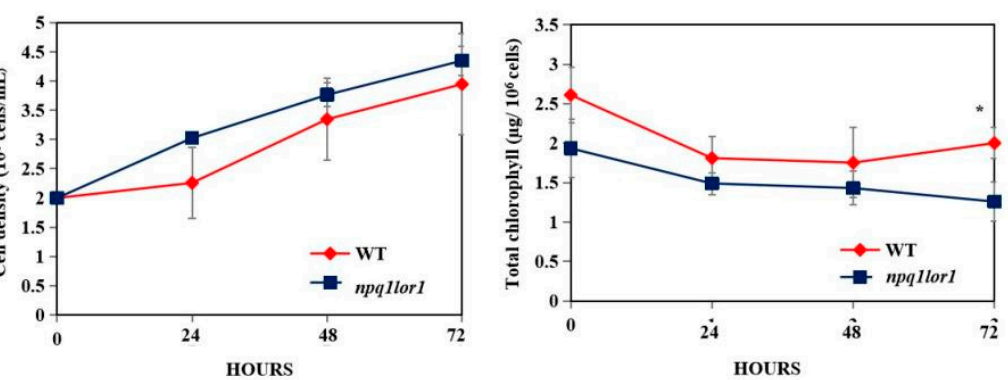

$20^{\circ} \mathbf{C}$
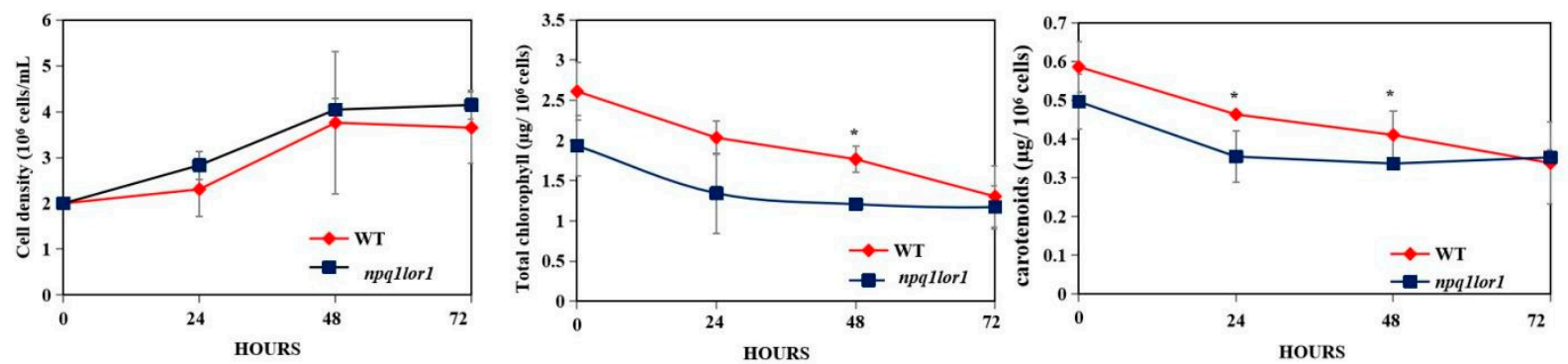

$25^{\circ} \mathrm{C}$

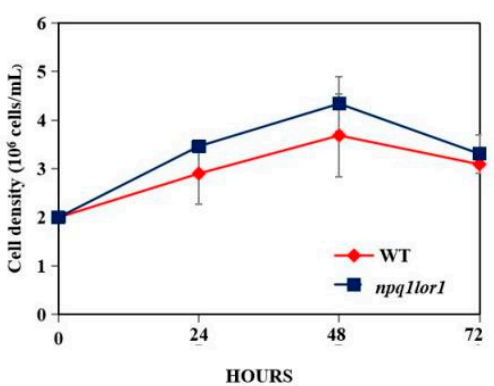

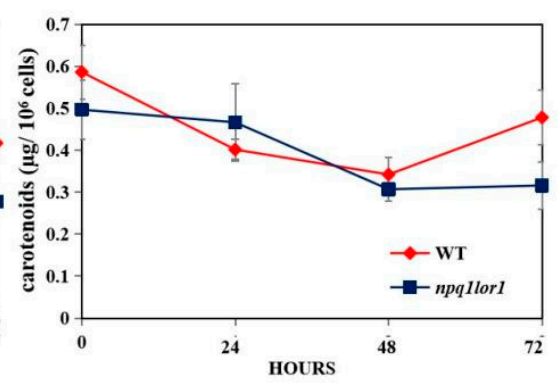

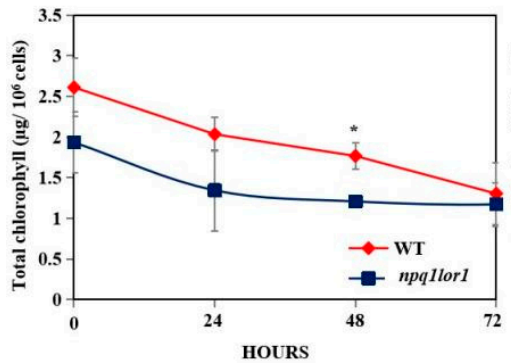

C
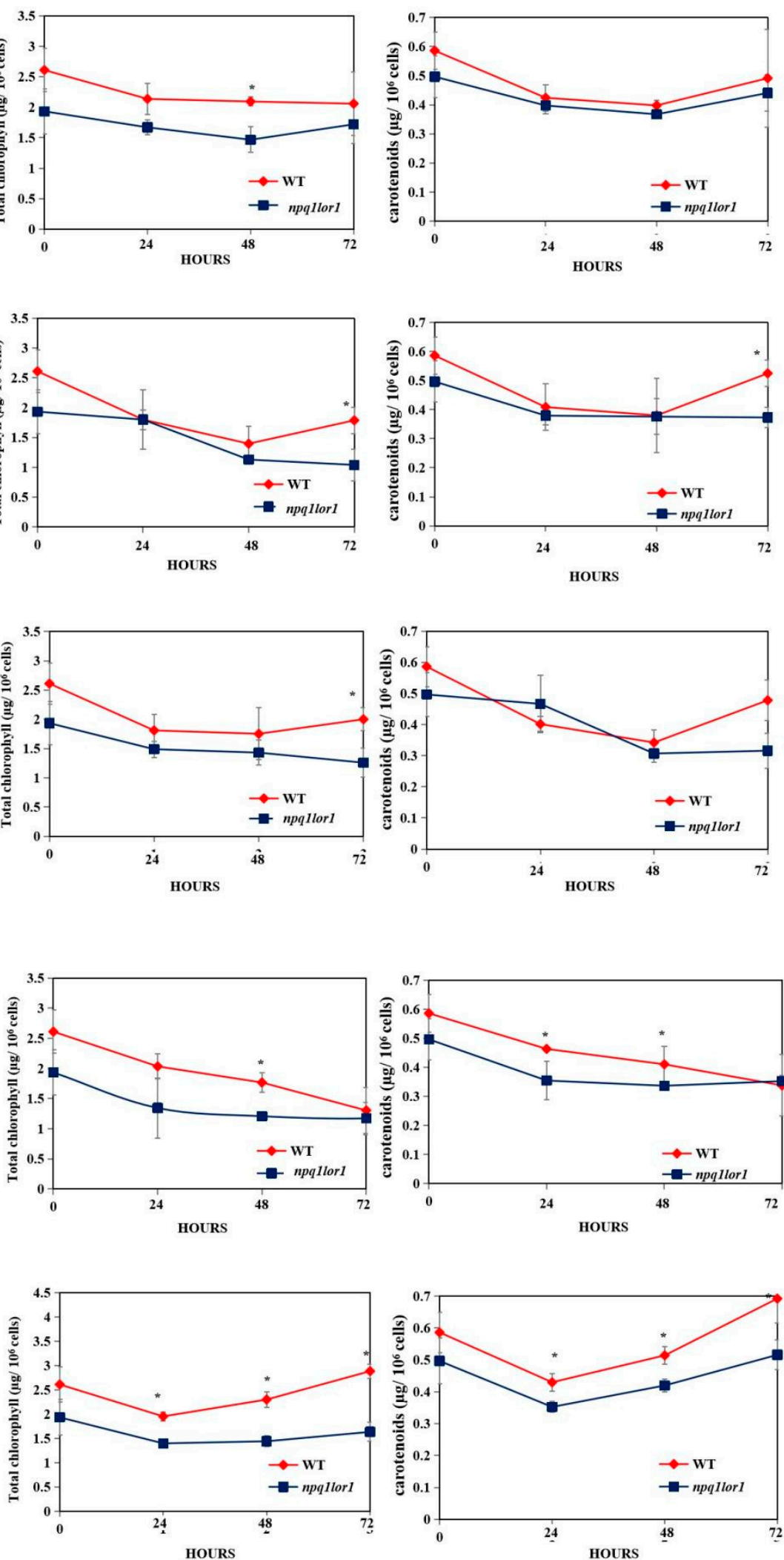

Figure 5. Growth (A), chlorophyll (B), and carotenoid (C) content of C. reinhardtii WT and npq1lor1 under different conditions. All data are means \pm SD of three biological replicates. Significant differences between WT and npq1 lor 1 mutant are indicated by asterisks $\left(^{*}\right)(p<0.05)$. 


\section{Conclusions}

The effects of cold temperature on cell physiology, especially pigment accumulation, was investigated in the mesophilic green alga Chlamydomonas reinhardtii. Cold temperature induced hyperaccumulation of chlorophyll and carotenoids. A temperature of $15^{\circ} \mathrm{C}$ was the best temperature for carotenoid and chlorophyll productivity, whereas $20^{\circ} \mathrm{C}$ was the best for biomass production. The lack of lutein and zeaxanthin did not result in a difference in cell survival under cold stress. Therefore, cold stress can be used to increase pigment yield in Chlamydomonas, and the carotenoid pigments lutein and zeaxanthin are not required for survival under this condition.

Author Contributions: Conceptualization, S.P., C.Y., and A.S.; methodology, S.P. and C.Y.; formal analysis, S.P. and A.S.; investigation, S.P. and A.S.; writing - original draft preparation, S.P. and A.S.; writing —-review and editing, A.S.; supervision, A.S.; project administration, A.S.; funding acquisition, A.S. All authors have read and agreed to the published version of the manuscript.

Funding: This research was funded by Basic Research Fund (BRF), the Faculty of Science, Kasetsart University, Kasetsart University Research and Development Institute (KURDI), and by the Graduate Program Scholarship from the Graduate School, Kasetsart University. The APC was funded by the Faculty of Science, Kasetsart University.

Institutional Review Board Statement: Not applicable.

Informed Consent Statement: Not applicable.

Data Availability Statement: Not applicable.

Acknowledgments: This work was funded by Basic Research Fund (BRF), the Faculty of Science, Kasetsart University, Kasetsart University Research and Development Institute (KURDI), and by the Graduate Program Scholarship from the Graduate School, Kasetsart University.

Conflicts of Interest: The authors declare that they have no known competing financial interests or personal relationships that could have appeared to influence the work reported in this paper.

\section{References}

1. Sanghera, G.S.; Wani, S.H.; Hussain, W.; Singh, N.B. Engineering cold stress tolerance in crop plants. Curr. Genom. 2011, 12, $30-43$. [CrossRef] [PubMed]

2. da Cruz, R.P.; Sperotto, R.A.; Cargnelutti, D.; Adamski, J.M.; de FreitasTerra, T.; Fett, J.P. Avoiding damage and achieving cold tolerance in rice plants. Food Energy Secur. 2013, 2, 96-119. [CrossRef]

3. Jeon, J.; Kim, J. Cold stress signaling networks in Arabidopsis. J. Plant Biol. 2013, 56, 69-76. [CrossRef]

4. Poiroux-Gonord, F.; Bidel, L.P.R.; Fanciullino, A.-L.; Gautier, H.; Lauri-Lopez, F.; Urban, L. Health benefits of vitamins and secondary metabolites of fruits and vegetables and prospects to increase their concentrations by agronomic approaches. J. Agric. Food Chem. 2010, 58, 12065-12082. [CrossRef] [PubMed]

5. Mortensen, A. Carotenoids and other pigments as natural Colorants. Pure Appl. Chem. 2006, 78, 1477-1491. [CrossRef]

6. Novoveská, L.; Ross, M.E.; Stanley, M.S.; Pradelles, R.; Wasiolek, V.; Sassi, J.F. Microalgal carotenoids: A review of production, current markets, regulations, and future direction. Mar. Drugs 2019, 17, 640. [CrossRef] [PubMed]

7. Ambrico, A.; Trupo, M.; Magarelli, R.; Balducchi, R.; Ferraro, A.; Hristoforou, E.; Marino, T.; Musmarra, D.; Casella, P.; Molino, A. Effectiveness of Dunaliella salina Extracts against Bacillus subtilis and Bacterial Plant Pathogens. Pathogens 2020, 28, 613. [CrossRef] [PubMed]

8. Harvey, P.J.; Ben-Amotz, A. Towards a sustainable Dunaliella salina microalgal biorefinery for 9-cisbeta-carotene production. Algal Res. 2020, 50, 102002. [CrossRef]

9. Tumolo, T.; Lanfer-Marquez, U.M. Copper chlorophyllin: A food colorant with bioactive properties? Food Res. Int. 2012, 46, 451-459. [CrossRef]

10. Perez-Galvez, A.; Viera, I.; Roca, M. Chemistry in the Bioactivity of Chlorophylls: An Overview. Curr. Med. Chem. 2017, 40, 4515-4536. [CrossRef]

11. Solymosi, K.; Mysliwa-Kurdziel, B. Chlorophylls and their Derivatives Used in Food Industry and Medicine. Mini Rev. Med. Chem. 2017, 13, 1194-1222. [CrossRef] [PubMed]

12. Harris, E.H. Chlamydomonas as a model organism. Annu. Rev. Plant Biol. 2001, 52, 363-406. [CrossRef] [PubMed]

13. Hosikian, A.; Lim, S.; Halim, R.; Danquah, M.K. Chlorophyll Extraction from Microalgae: A Reviewon the Process Engineering Aspects. Int. J. Chem. Eng. 2010, 2010, 391632. [CrossRef] 
14. Couso, I.; Vila, M.; Vigara, J.; Cordero, B.F.; Vargas, M.Á.; Rodríguez, H.; León, R. Synthesis of carotenoids and regulation of the carotenoid biosynthesis pathway in response to high light stress in the unicellular microalga Chlamydomonas reinhardtii. Eur. J. Phycol. 2012, 47, 223-232. [CrossRef]

15. Fields, F.J.v.; Lejzerowicz, F.; Schroeder, D.; Ngoi, S.M.; Tran, M.; McDonald, D.; Mayfield, S. Effects of the microalgae Chlamydomonas on gastrointestinal health. J. Funct. Foods 2020, 65, 103738. [CrossRef]

16. Murbach, T.S.; Glávits, R.; Endres, J.R.; Hirka, G.; Vértesi, A.; Béres, E.; Szakonyiné, I.P. A toxicological evaluation of Chlamydomonas reinhardtii, a green algae. Int. J. Toxicol. 2018, 37, 53-62. [CrossRef] [PubMed]

17. Darwish, R.; Gedi, M.A.; Eakpetch, P.; Assaye, H.; Zaky, A.S.; Gray, D.A. Chlamydomonas reinhardtii Is a Potential Food Supplement with the Capacity to Out perform Chlorella and Spirulina. Appl. Sci. 2020, 10, 6736. [CrossRef]

18. Miguez, F.; Holzinger, A.; Fernandez-Marin, B.; Garcia-Plazaola, G.I.; Karsten, U.; Gustavs, L. Eco physiological changes and spore formation: Two strategies in response to low-temperature and high-light stress in Klebsormidium cf. flaccidum (Klebsormidiophyceae, Streptophyta). J. Phycol. 2020, 15, 649-661. [CrossRef]

19. Soufi, S.; Rezgui, S.; Bettaeib, T. Early effects of chilling stress on the morphological and physiological status of pretreated Stevia rebaudiana Bert. seedlings. J. New Sci. 2015, 14, 467-472.

20. Baroli, I.; Gutman, B.L.; Ledford, H.K.; Shin, J.W.; Chin, B.L.; Havaux, M.; Niyogi, K.K. Photo-oxidative Stress in a Xanthophylldeficient Mutant of Chlamydomonas. J. Biol. Chem. 2003, 279, 6337-6344. [CrossRef]

21. Niyogi, K.K.; Björkman, O.; Grossman, A.R. The roles of specific xanthophylls in photoprotection. Proc. Natl. Acad. Sci. USA 1997, 94, 14162-14167. [CrossRef]

22. Lichtenthaler, H.K. Chlorophylls and carotenoids: Pigments of photosynthetic bio membranes. Methods Enzymol. 1987, 148, 350-382.

23. Sirikhachornkit, A.; Vuttipongchaikij, S.; Suttangkakul, A.; Yokthongwattana, K.; Juntawong, P.; Pokethitiyook, P.; Kangvansaichol, K.; Meetam, M. Increasing the Triacylglycerol Content in Dunaliella tertiolecta through Isolation of Starch-Deficient Mutants. J. Microbiol. Biotechnol. 2016, 28, 854-866. [CrossRef] [PubMed]

24. Anschau, A.; Caruso, C.S.; Kuhn, R.C.; Franco, T.T. Validation of the sulfo-phospho vanillin SPV method for the determination of lipid content in oleaginious microorganisms. Braz. J. Chem. 2017, 34, 19-27. [CrossRef]

25. Hempel, N.; Petrick, I.; Behrendt, F. Biomass productivity and productivity of fatty acids and amino acids of microalgae strains as key characteristics of suitability for biodiesel production. J. Appl. Phycol. 2012, 24, 1407-1418. [CrossRef] [PubMed]

26. Valledor, L.; Furuhashi, T.; Hanak, A.M.; Weckwerth, W. Systemic cold stress adaptation of Chlamydomonas reinhardtii. Mol. Cell. Proteom. 2013, 12, 2032-2047. [CrossRef] [PubMed]

27. Butterwick, C.; Heaney, S.I.; Talling, J.F. Diversity in the influence of temperature on the growth rates of freshwater algae, and its ecological relevance. Fresh Biol. 2005, 50, 291-300. [CrossRef]

28. Kudo, I.; Miyamoto, M.; Noiri, Y.; Maita, Y. Combined effects of temperature and iron on the growth and physiology of the marine diatom Phaeodactylum tricornutum (Bacillariophyceae). J. Phycol. 2000, 36, 1096-1102. [CrossRef]

29. Xin, L.; Hong-ying, H.; Yu-ping, Z. Growth and lipid accumulation properties of a freshwater microalga Scenedesmus sp. under different cultivation temperature. Bioresour. Technol. 2011, 102, 3098-3102. [CrossRef] [PubMed]

30. Araújo, R.; Calderón, F.V.; López, J.S.; Azevedo, I.C.; Bruhn, A.; Fluch, S.; Ullmann, J. Current status of the algae production industry in Europe: An emerging sector of the Blue Bioeconomy. Front. Mar. Sci. 2021, 7, 1247. [CrossRef]

31. Pankratz, S.; Oyedun, A.O.; Zhang, X.; Kumar, A. Algae pro-duction platforms for Canada's northern climate. Renew. Sust. Energy Rev. 2017, 80, 109-120. [CrossRef]

32. Pankratz, S.; Oyedun, A.O.; Kumar, A. Development of cost models of algae production in a cold climate using different production systems. Biofuels Bioprod. Biorefining 2019, 13, 1246-1260. [CrossRef]

33. Huo, S.; Wang, Z.; Zhu, S.; Zhou, W.; Dong, R.; Yuan, Z. Cultivation of Chlorella zofingiensis in bench-scale outdoor ponds by regulation of $\mathrm{pH}$ using dairy wastewater in winter, South China. Bioresour. Technol. 2012, 121, 76-82.

34. Paliwal, C.; Mitra, M.; Bhayani, K.; Bharadwaj, S.V.; Ghosh, T.; Dubey, S.; Mishra, S. Abiotic stresses as tools for metabolites in micro-algae. Bioresour. Technol. 2017, 244, 1216-1226. [CrossRef] [PubMed]

35. Geider, R.; La-Roche, J. Redfield. revisited: Variability of C:N:P in marine microalgae and its biochemical basis. Eur. J. Phycol. 2002, 37, 1-17. [CrossRef]

36. Smith, A.M.; Zeeman, S.C.; Smith, S.M. Starch degradation. Annu. Rev. Plant Biol. 2005, 56, 73-98. [CrossRef] [PubMed]

37. Ali-zadeh, G. Low temperature stress increases Dunaliella cells population resistance to the effect of chronic dozes of UV-B radiation. CIB Tech. J. Biotechnol. 2012, 1, 36-39.

38. Gilstad, M.; Johnsen, G.; Sakshaug, E. Photosynthetic parameters, pigment composition and respiration rates of the marine diatom Skeletonema costatum grown in continuous light and a 12/12 h light-dark cycle. J. Plankton Res. 1993, 15, 939-951. [CrossRef]

39. Maikova, A.; Zalutskaya, Z.; Lapina, T.; Ermilova, E. The HSP70 chaperone machines of Chlamydomonas are induced by cold stress. J. Plant Physiol. 2016, 204, 85-91. [CrossRef]

40. Suzuki, N.; Mittler, R. Reactive oxygen species and temperature stresses: A delicate balance between signaling and destruction. Physiol. Plant. 2006, 126, 45-51. [CrossRef]

41. Juszczak, I.; Cvetkovic, J.; Zuther, E.; Hincha, D.K.; Baier, M. Natural Variation of Cold Deacclimation Correlates with Variation of Cold-Acclimation of the Plastid Antioxidant System in Arabidopsis thaliana Accessions. Front. Plant Sci. 2016, 7, 305. [CrossRef] [PubMed] 
42. O'Kane, D.; Gill, V.; Boyd, P.; Burdon, R. Chilling oxidative stress and antioxidant responses in Arabidopsis thaliana callus. Planta 1996, 198, 371-377. [CrossRef] [PubMed]

43. Shi, H.; Ye, T.; Zhong, B.; Liu, X.; Chan, Z. Comparative proteomic and metabolomic analyses reveal mechanisms of improved cold stress tolerance in bermudagrass (Cynodon dactylon (L.) Pers.) by exogenous calcium. J. Integrat. Plant Biol. 2014, 56, 1064-1079. [CrossRef] [PubMed]

44. Zalutskaya, Z.; Skryabina, U.S.; Ermilova, E.V. Generation of hydrogen peroxide and transcriptional regulation of antioxidant enzyme expression in Chlamydomonas reinhardtii under hypothermia. Russ. J. Plant Physiol. 2019, 66, 223-230. [CrossRef]

45. Ye, Z.W.; Jiang, J.G.; Wu, G.H. Biosynthesis and regulation of carotenoids in Dunaliella: Progresses and prospects. Biotechnol. Adv. 2008, 26, 352-360. [CrossRef] [PubMed]

46. Niyogi, K.K. Photoprotection revisited: Genetics and molecular approaches. Annu. Rev. Plant Physiol. Plant Mol. Biol. 1999, 50, 333-359. [CrossRef]

47. Chua, E.T.; Dal'Molin, C.; Thomas-Hall, S.; Netzel, M.E.; Netzel, G.; Schenk, P.M. Cold and dark treatments induce omega-3 fatty acid and carotenoid production in Nannochloropsis oceanica. Algal Res. 2020, 51, 102059. [CrossRef]

48. Ip, P.-F.; Chen, F. Production of astaxanthin by the green microalga Chlorella zofingiensis in the dark. Process Biochem. 2005, 40, 733-738. [CrossRef]

49. Seel, W.; Baust, D.; Sons, D.; Albers, M.; Etzbach, L.; Fuss, J.; Lipski, A. Carotenoids are used as regulators for membrane fluidity by Staphylococcus xylosus. Sci. Rep. 2020, 10, 1-12. [CrossRef] [PubMed]

50. Zakar, T.; Herman, E.; Vajravel, S.; Kovacs, L.; Knoppová, J.; Komenda, J.; Domonkos, I.; Kis, M.; Gombos, Z.; Laczko-Dobos, H. Lipid and carotenoid cooperation-driven adaptation to light and temperature stress in Synechocystis sp. PCC6803. Biochim. Biophys. Acta 2017, 1858, 337-350. [CrossRef]

51. Pogson, B.; McDonald, K.A.; Truong, M.; Britton, G.; DellaPenna, D. Arabidopsis carotenoid mutants demonstrate that lutein is not essential for photosynthesis in higher plants. Plant Cell. 1996, 8, 1627-1639. [PubMed]

52. Alboresi, A.; Dall'Osto, L.; Aprile, A.; Carillo, P.; Roncaglia, E.; Cattivelli, L.; Bassi, R. Reactive oxygen species and transcript analysis upon excess light treatment in wild-type Arabidopsis thaliana vs a photosensitive mutant lacking zeaxanthin and lutein. BMC Plant Biol. 2011, 11, 1-22. [CrossRef] [PubMed]

53. Niyogi, K.K.; Shih, C.; Chow, W.S.; Pogson, B.J.; DellaPenna, D.; Björkman, O. Photoprotection in a zeaxanthin-and lutein-deficient double mutant of Arabidopsis. Photosynth. Res. 2001, 67, 139-145. [CrossRef] [PubMed] 